\title{
11
}

\section{TOWARDS AN ALIEN COMMUNITY OF DANCING WITCHES IN EARLY SEVENTEENTH-CENTURY EUROPE ${ }^{*}$}

\section{Charles Zika}

THE UNIVERSITY OF MELBOURNE

Strategies of exclusion are at the heart of the phenomenon of the European witch-hunt. The witches of early modern Europe were generally understood to be extremely malicious and aggressive figures; for this reason, they had to be excluded from the benefits and protections of church and state. They had to be made alien, to be created as other; indeed, they had to appear alien and other. "Otherness" was projected onto them, and their projected emotions were key to how observers would in turn feel about them, namely, that such vile creatures had no place in their own society. While closer attention has recently been given to the rhetorical techniques used to shape the responses of those reading texts describing the activities of witchcraft, ${ }^{1}$ little close attention has been given to the visual strategies used by artists to stimulate similar emotions in their viewers. Even less consideration has been given to the emotions deeply encoded in the visualized behaviour of witches, that is, the emotions witches were shown performing in visual media. In a Europe in which literacy was still limited outside the major urban centres, visual media served to distance witches from their viewers as alien and in many cases to represent them as a moral, social, political, or even physical threat. ${ }^{2}$

In this chapter, I want to explore how the witches' dance, and emotions performed in the depictions of that dance, showed witches transgressing the behavioural and emotional norms of Christian society, thereby identifying them as outsiders and a potential threat that required their prosecution, expulsion, or

\footnotetext{
* Thanks to Julie Davies and Jenny Smith for assistance with different aspects of this article, and to Giovanni Tarantino and Jenny Spinks for their fruitful suggestions. The research was funded by the Australian research Council Centre of Excellence for the History of Emotions (project number CE110001011).
} 
even extermination. A curious aspect of the witches' dance is that it was almost completely absent from images of witchcraft before the last decade of the sixteenth century. While the dance certainly featured in earlier literary representations of witchcraft and in trial testimony, it is only from the 1590s that it becomes incorporated into visual images, and in particular into scenes of witches' meetings or Sabbaths. This suggests that prior to the last two decades of the sixteenth century, witches' dances had not yet become a fundamental and universal component of the Sabbath and of what is frequently referred to as 'the cumulative concept of witchcraft'. ${ }^{3}$ By the late seventeenth century, however, the witches' dance had become almost synonymous with the Sabbath. Yet the witches' dance has not been given any serious scholarly attention, and the most comprehensive witchcraft encyclopedia does not include an entry. ${ }^{4}$ This chapter will explore how and why the witches' dance emerged as a way of depicting witches as members of a totally alien community that presented Christian society with a serious threat. It will therefore focus on the period up to the turn of the seventeenth century when witches' dances began to appear in visual media, and will examine both visual and literary sources in order to clarify the forms dancing took and the conceptual and emotional messages it sought to convey.

I want to first consider a remarkable early seventeenth-century image that illustrates how central dancing had become to depictions of witchcraft by this time. The image I offer-a 1626 print by the prominent Frankfurt artist, Matthäus Merian the Elder, based on a design of a less well-known, but significant Nuremberg painter and engraver, Michael Herr (Figure 11.1) - is also important because of the influence it exerted on witchcraft images well into the eighteenth century. ${ }^{5}$ This striking scene of pandemonium survives in two formats. One version is simply entitled Zauberey (Witchcraft) and includes Latin verses below by Johann Ludwig Gottfried, a historian and Reformed theologian from the Palatinate, who worked for Merian in Frankfurt from 1624 as a proofreader, while also a pastor in Offenbach. Beneath the Latin verses are five columns of verses by an unknown author in German. A second version includes a longer caption above (Figure 11.1), and German verses by Johann Claj below. ${ }^{6}$ The broadsheet was the work of a number of highly respected artists and writers from southern Germany.

The image itself conveys a strong sense of frenzy, a turbulence created by billowing smoke and gas, bodies tumbling and flying through the air, an almost audible cacophony created by the raucous dancers, a shrieking witch, and hybrid spirits-some screaming with mouths agape and others beating drums. The emotional pull is electric, and it draws on the theatricality, energy, and movement found in the work of other artists: the paintings and prints of Frans Francken the Younger created approximately fifteen to twenty years earlier; the drawings of Jacques de Gheyn the Younger, and in particular, the only drawing he intentionally released for broader circulation through a 1610 engraving; and most especially, the 1613 etching of the Polish artist, Jan Ziarnko, inserted in the second edition of Pierre de Lancre's Description of the Inconstancy of Evil 


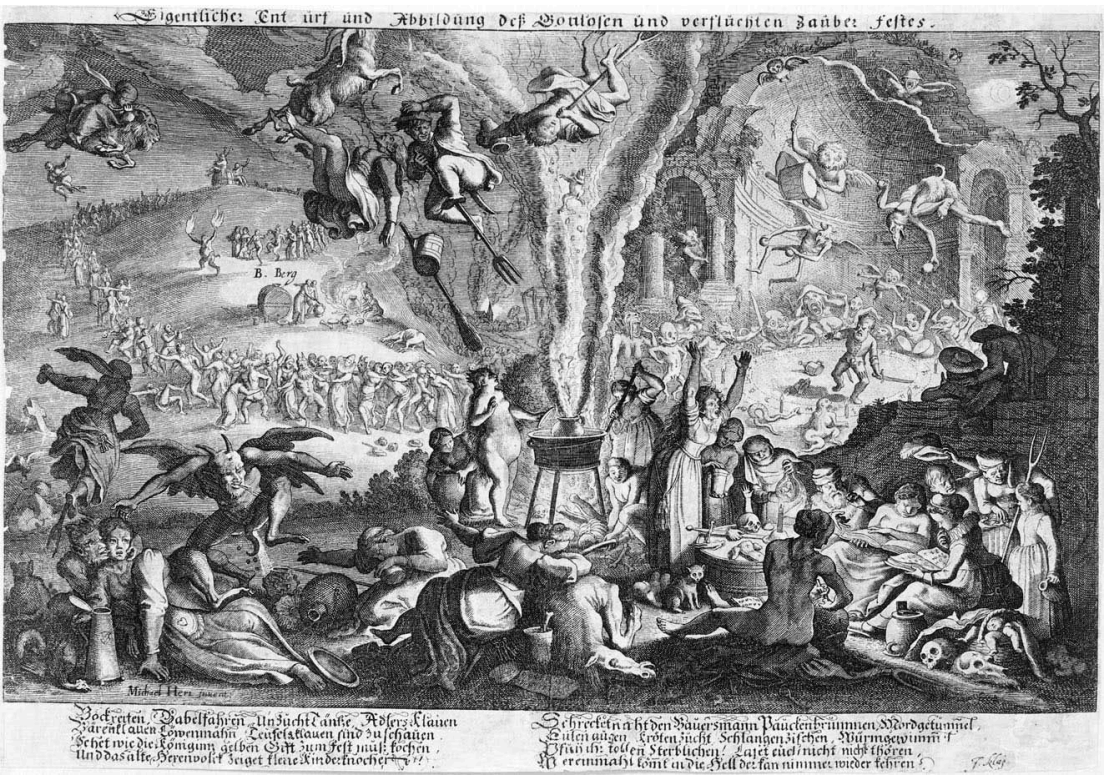

FIGURE 11.1 Matthäus Merian, after Michael Herr, A Precise Sketch and Depiction of an Ungodly and Cursed Witches' Festival, c.1626 (?), etching. Germanisches Nationalmuseum, Graphische Sammlung, HB25872.

Angels and Demons, to illustrate the witches' Sabbath in the Basque country. ${ }^{7}$ Such borrowings and influences are also clearly seen in two of Michael Herr's surviving drawings, generally considered to be preparatory drawings for this later broadsheet. ${ }^{8}$

The upper left section of the print (Figure 11.2), which features a witches' dance in which masses of male and female witches swarm around and up a mountain labelled 'Blocksberg', seems original in much of its imagery. The Blocksberg (also called the Brocken) was the highest of the Harz Mountains of central Germany, and from the later sixteenth century it became well known as one of the most significant locations for witches' assemblies and dances. ${ }^{9}$ Here the dancers follow their satyr-like leader, Satan, depicted with raised flaming arms; while interspersed among witches in the gyrating line of dancers are musicians and devils, one of them in full frontal naked pose, with whom the female witches dance wildly and perform sexual acts. The dancers convey a loss of emotional and bodily control, a view supported by the wine barrels half way up and at the top of the mountain, and the inebriated figures in the left foreground, including a lewd devil groping a drunken woman in front of a large tankard, his tongue sticking out as he draws near to her cheek and wraps a leg around her waist. The scene above is framed by a witch riding a goat, while another, possibly thrown off by the force of the vapours spewing from the cauldrons below, reveals her bare buttocks and genitals. ${ }^{10}$ 


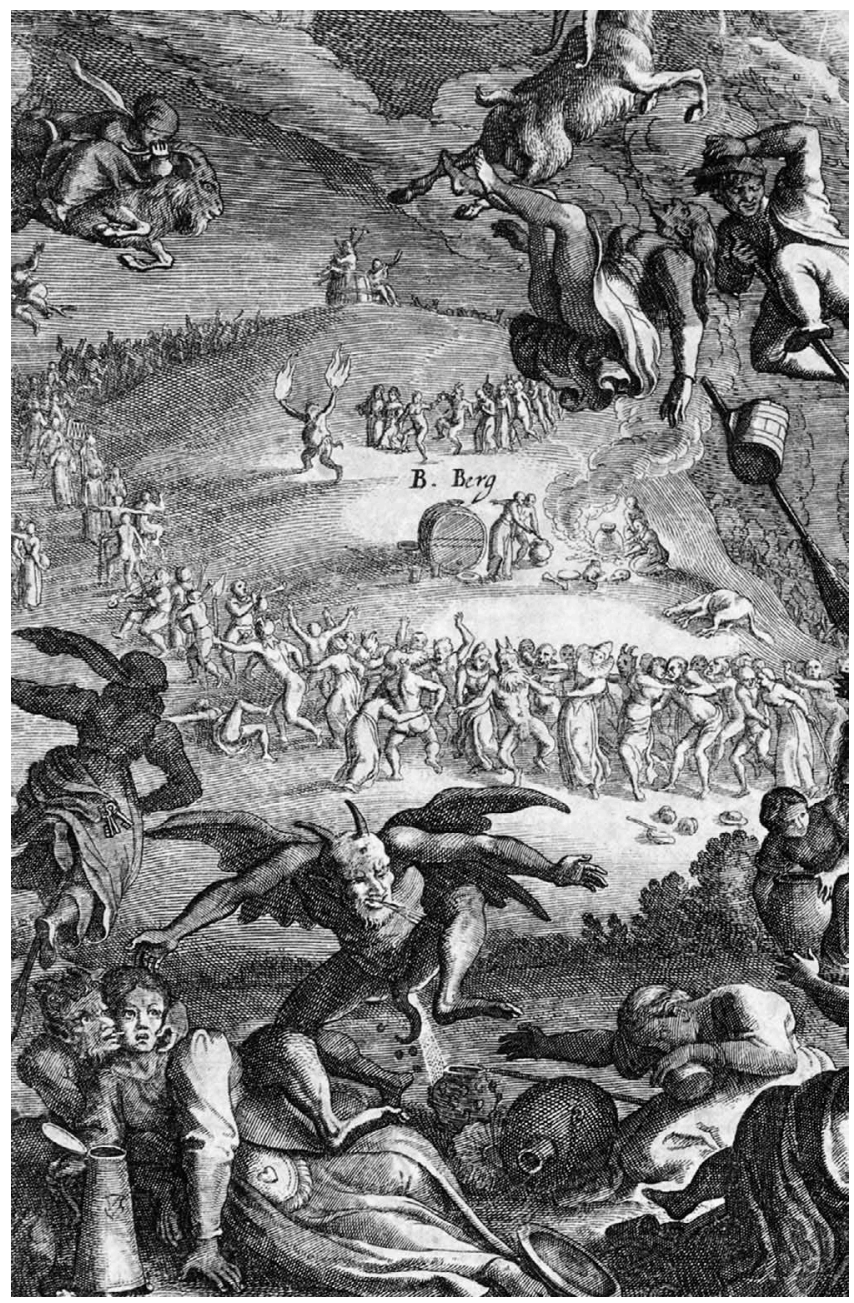

FIGURE 11.2 Matthäus Merian, after Michael Herr, A Precise Sketch and Depiction of an Ungodly and Cursed Witches' Festival (detail), c.1626 (?), etching. Germanisches Nationalmuseum, Graphische Sammlung, HB25872.

Uncontrolled lechery, the flaunting of sensual bodies, jagged and gyrating movement - the erotic and the erratic-are on full view. The witches' dance in this broadsheet by Merian, then, represents witches as governed by their lusts and their inability to control their base desires. Added to this are examples of the destructive nature and outcomes of witches' activities (Figure 11.1): the small group of women around the cauldron in the centre of the print, with its strewn bones and the emaciated cadaver of a horse nearby; a dead horse in the centre foreground; a human cadaver and skull under the central cauldron; the skulls and dead baby visible under a cover by the group of witches following 
magical rituals in the right foreground; and the burning church and town in the middle distance, the gallows and wheel suggesting that this too was the destructive work of these criminals.

The message of the print is also partly related to the massed character of the scene. These are not simply individuals; this is society at work. Witches are members of a truly frenzied and destructive society, involving innumerable adepts and rampaging devils that are shown stretching around the mountain following their Satanic leader. In that way the print makes visible the 'terrifying, alien, chaotic and wild' nature of the scene described in the German verses below. ${ }^{11}$ Lack of bodily control signals the domination of the senses and lust, as well as a lack of emotional control. The lack of moral order suggests the threat to the social order. These witches are certainly meant to stimulate curiosity in the viewer. But given their large numbers, they represent a society - a large, odious, and destructive society - and this incites fear, threat, even terror. This combination of factors, I believe, is why the new image of a wild processional dance captures the imagination of so many artists through to the mid-eighteenth century. ${ }^{12}$ But how and why did such images of witchcraft take root from the 1590s? To attempt an answer, we need first to survey witches' dances from the fifteenth century.

The first known case of witches' dances occurs in a Flemish miniature found in one of the four different surviving French versions of a Treatise against the Sect of the Waldensians, written by the Cologne theologian Johann Tinctor in the wake of the Vauderie of Arras. ${ }^{13}$ This involved the prosecution of a group of male and female Waldensians in the northern French town of Arras in 1459-1460, who were accused of worshipping the Devil in the form of various animals and riding implements and beasts through the air in the manner of witches. In a manuscript of c.1460-1470, the group are depicted performing the ritual of the obscene kiss in a village street setting, each of the four devotees holding a candle, one with pursed brown lips to suggest she has just kissed the backside of the goat (Figure 11.3). Three of their female colleagues ride a scythe, a broom, and a spindle through the sky, and a fourth is just emerging from a chimney. In the left background, moreover, two couples-whether female Waldensians and devils is unclear-are shown dancing (Figure 11.4). The male of one couple is quite prominent, the jewellery around his neck glistening as he lifts one arm in a flamboyant move, while clasping his partner's hand with the other. The second couple is clearly engaged in sexual play, with the female's arms clasped around the shoulders of her male partner, her over-garment drawn back as his left hand is strategically placed near the woman's genital area. Waldensian witchcraft clearly involved dancing and sexual pleasure, according to this artist, even if that was somewhat in the background, as it is compositionally in this illumination. ${ }^{14}$ Indeed, Martin le Franc's long allegorical poem of 1451, Le Champion des Dames, described a similar 'synagogue' (as it was called) involving the ritual of the obscene kiss in the valley of Valpute. As well as the learning of perverse arts and sorceries from the Devil, and much feasting and drinking, le Franc also refers to dancing, even if only in a single line: 'some would take their pleasure in dance'. ${ }^{15}$ 


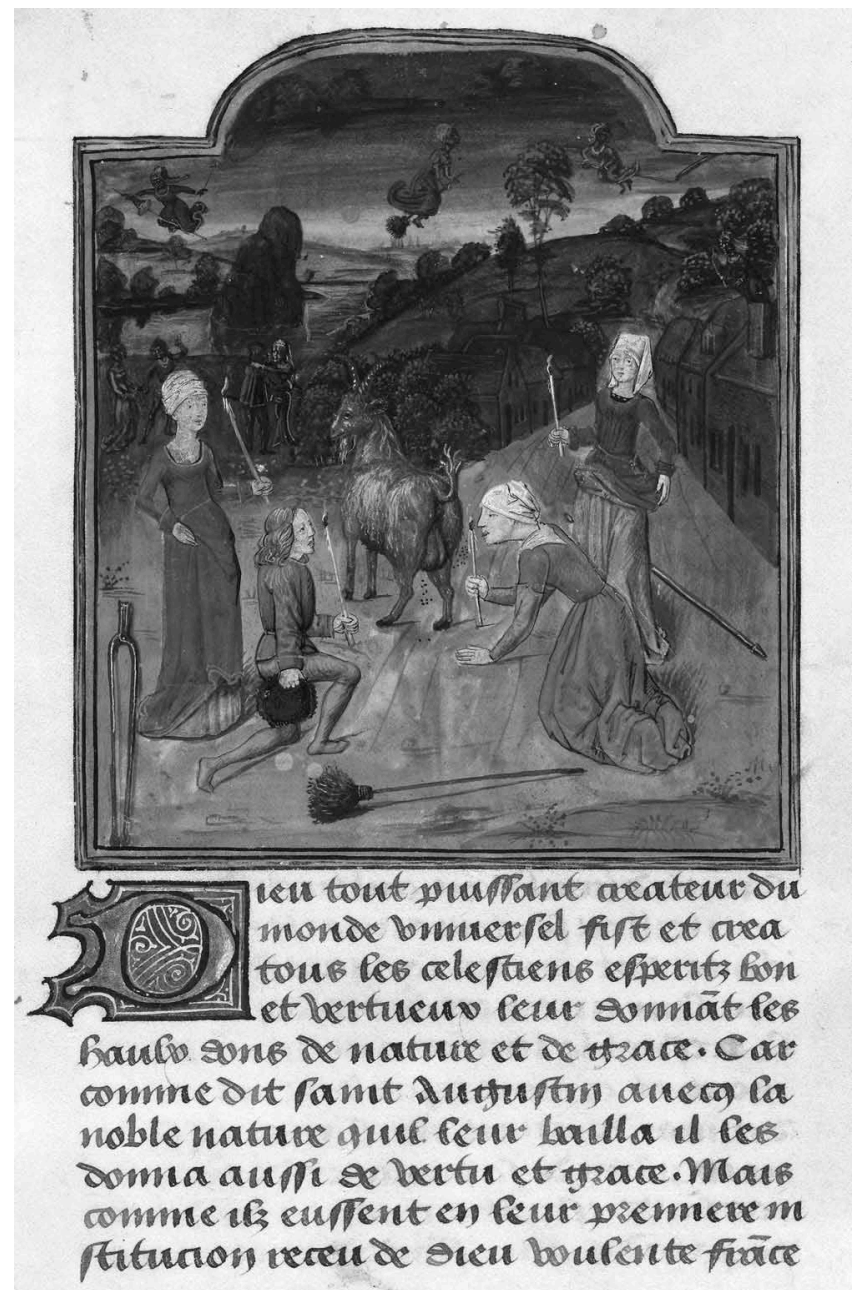

FIGURE 11.3 Waldensians Worshipping the Devil, illumination, in Johannes Tinctor, Tractatus contra sectam Valdensium, c.1470. Bodleian Libraries, University of Oxford, MS Rawl D. 410, fol. 1r.

Images of devils dancing with female partners certainly do exist, such as the wedding of the Devil and Injustice surrounded by musicians, found in illustrated manuscripts of Hans Vintler's Book of Virtues. ${ }^{16}$ But the dance is not with witches. Likewise, the various woodcuts depicting the embrace of a witch and the Devil, found in more than twenty illustrated editions of Ulrich Molitor's On Female Witches and Seers published by 1510, show no more than a sensual and lewd embrace signifying the sexual nature of the diabolical pact. ${ }^{17}$ The only images of witches dancing that I have found between the Waldensian witches of c.1460-1470 and images of a century later are in three Paris versions of the 


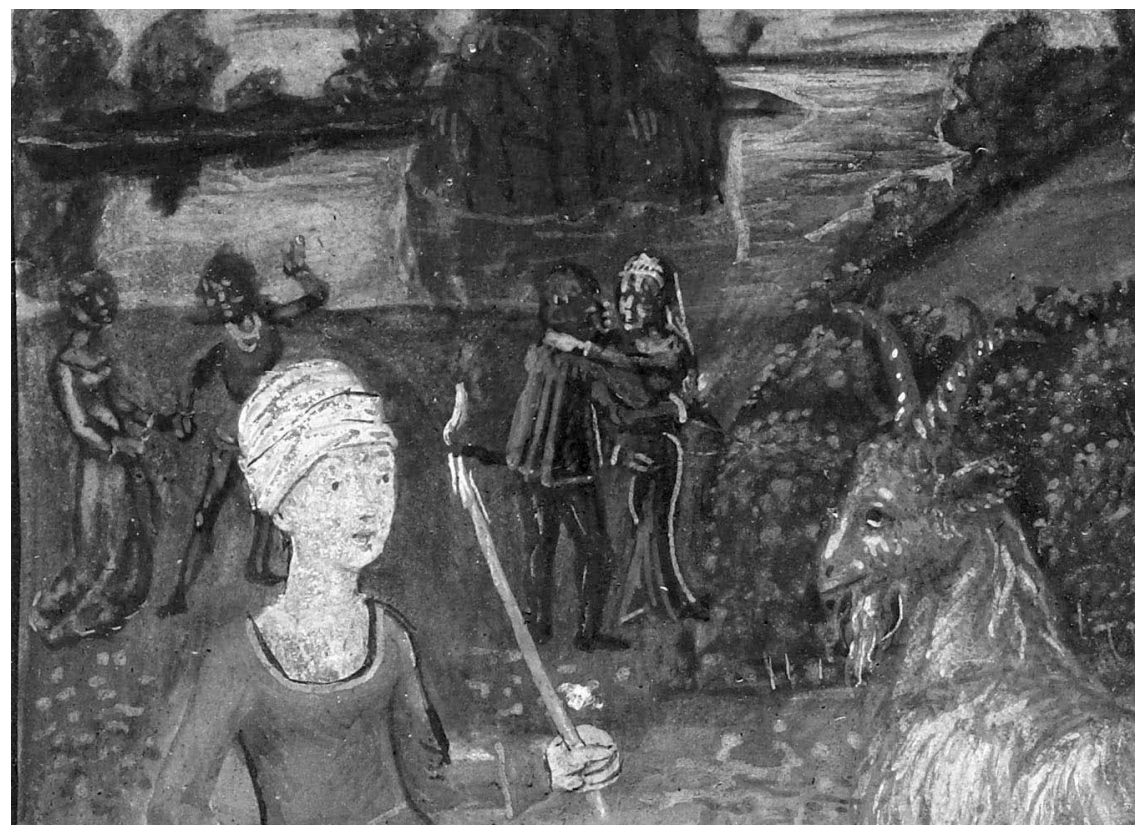

FIGURE 11.4 Waldensians Worshipping the Devil (detail), illumination, in Johannes Tinctor, Tractatus contra sectam Valdensium, c.1470. Bodleian Libraries, University of Oxford, MS Rawl D. 410, fol. 1r.

Women's Dance of Death of 1491, 1499, and c.1500. ${ }^{18}$ While suggestive of the emergence of the witch as a particular (female) social category in the late fifteenth century, and informative concerning her symbolic attributes, these images tell us nothing about the relationship of witches and dancing.

Witches dancing with devils finally appear in a number of drawings illustrating trial evidence collected by the Zurich pastor Johann Jakob Wick for his 'Wonderbook', a mass of diverse documentary and visual material now in twenty-four folio volumes documenting the state of Europe between 1560 and 1587. ${ }^{19}$ Accompanying the account of a mother and daughter who were tried and executed for witchcraft in Berne in August 1568, a coloured pen and ink drawing depicts the wedding feast celebrating the marriage of the two women with devils (Figure 11.5). It is significant that the court trying these women first considered their account as a case of diabolical fantasy and deception. ${ }^{20}$ The illustration, however, depicts what later convinced them that the two women should be condemned to death. A devil is shown warming the food for the wedding feast, while his two colleagues dance with their new brides to the sound of drum and fife.

A notable aspect of this striking, though quite unsophisticated, drawing is that the three groups of figures at top left - the musicians, the dancing mother and her diabolic consort, and the figure wrapped around the tree-all bear a marked 


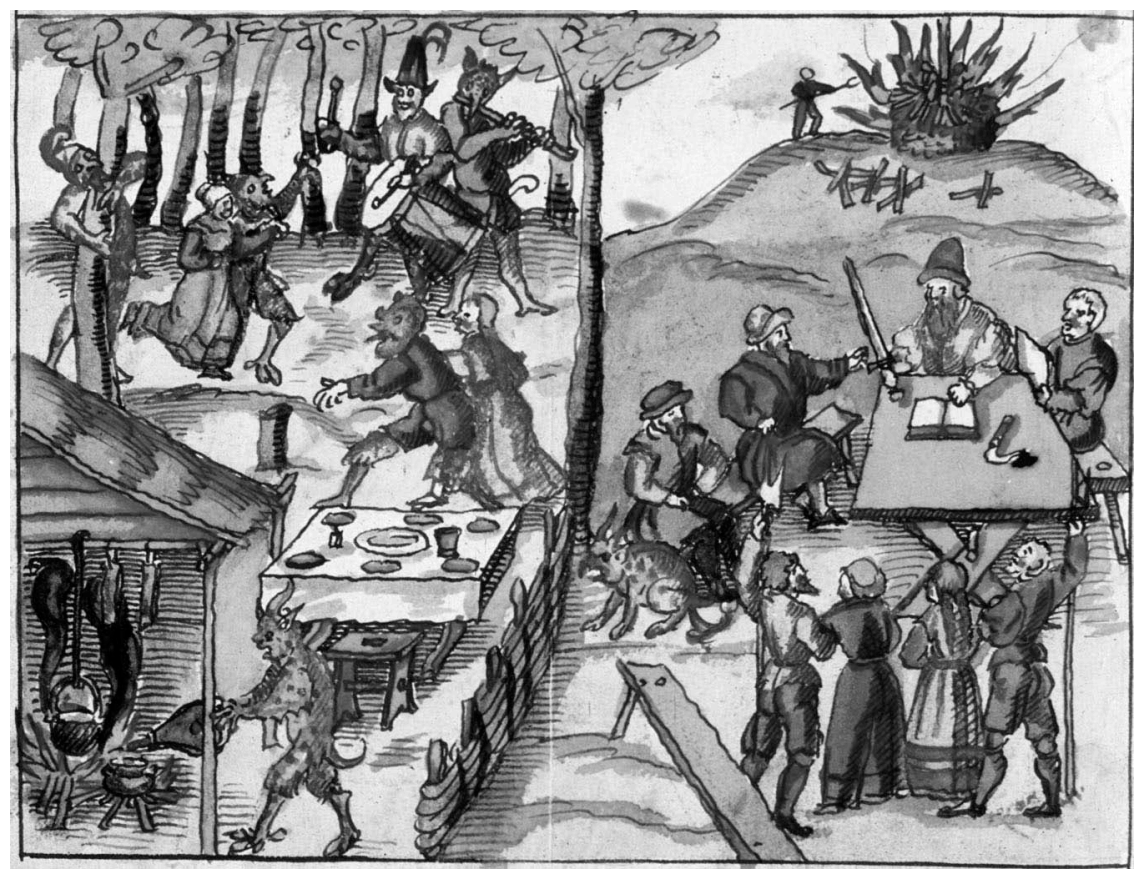

FIGURE 11.5 A mother and daughter dance at their wedding with devils; then they are tried and executed as witches in Berne in 1568, pen and ink, coloured, in Wickiana, F. 18, fol. 146v. Zentralbibliothek, Zurich.

similarity to the main figures in Lucas van Leyden's 1519 engraving of The Dance of Mary Magdalene (Figure 11.6). The central scene in that print depicts Mary Magdelene's sinful life before her conversion, dressed as a courtesan and led by her partner in a dance in an outdoor setting amongst a group of couples making love and song. An unusual theme in visual media prior to the sixteenth century, a dancing and singing Magdalene appeared in many medieval passion plays, in some cases dancing with Lucifer and other demons. ${ }^{21}$ Although haloed, in recognition of her later sainthood, the Magdelene's sinful behaviour is visibly called out by the figure of a gesturing fool emerging from behind a tree on the left perimeter of the print. That fool figure, a common reference to immorality in late medieval illustration, makes sense of the puzzling figure to the left of the wedding dance in the Wick illustration, shown straddling and peering out from behind a tree.

It seems like the unknown artist was familiar with Lucas van Leyden's print when he set about to represent evidence from a Berne witchcraft trial fifty years later, and he may have been also aware of the role Magdalene played in contemporary passion plays. So he included the fool figure, in case any viewer was seduced by the energy and joy of the diabolical feast. Indeed, in 1574 when a woman from Bremgarten, Regula Mayerin, and her daughter, Anna 


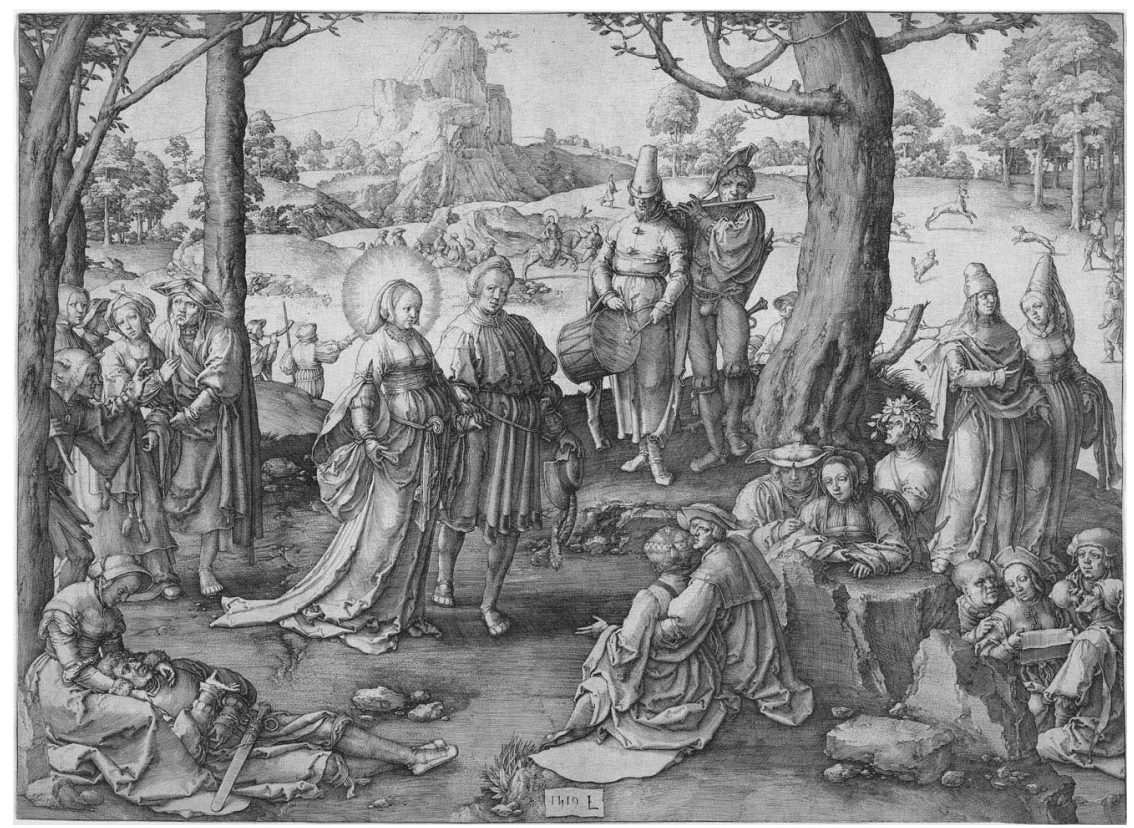

FIGURE 11.6 Lucas van Leyden, The Dance of Mary Magdalene, 1519, engraving, 28.7 x $39.5 \mathrm{~cm}$. Metropolitan Museum of Art, Harris Brisbane Dick Fund, 1927, Accession No. 27.5.3. Public Domain.

Langin, confessed to having had sex with the very same devil (named Lüzelhüpsch), another not quite so proficient artist decided to copy the drawing used to illustrate the Berne case of six years earlier-and he also included a figure wrapped around a tree, more obviously demonic in appearance than the one in the earlier image. ${ }^{22}$ These dances with devils were clearly not routine or ritualized events associated with witches more generally. As dancing represented a propensity to sensual pleasure and possibly sexual lust in traditional Christian culture, in these few cases it emphasized the sinful nature of the witch's diabolical pact and strongly suggested an incapacity to keep sensual desires in check.

In literary sources, dancing was more often linked to witchcraft through accounts of witches' meetings or assemblies. One early source for the witches' dance, especially in Italy, is the set of folkloric traditions associated with the walnut tree of Benevento. These traditions originated with a tree-worshipping cult of the Lombards in the seventh century, and a particular walnut tree was subsequently associated with harmful individuals and evil effects, as well as those, like witches, considered to be the source of such evil acts. ${ }^{23}$ St Bernardino of Siena, for instance, referred to the tree in a 1427 sermon, in which he described how a cardinal's page went to Benevento one night and when he saw 'women and children and young people dancing in an open field', he himself joined in 
and they all continued dancing till the bells struck matins. Although Bernardino's story did not mention any diabolical involvement with these predominantly female dancers, a whole night of dancing linked them to the periodic assemblies of women belonging to the Society of the pagan goddess Diana and to stories of the Italian tregenda, regular night conventicles that gradually morphed into the witches' Sabbath. Bernardino identified these night dancers as 'enchanters' or witches, who had to be 'exterminated'. ${ }^{24}$ A year later in the central Italian town of Todi, a female sorcerer and healer, Matteuccia di Francesco, was burnt as a witch for the invocation of spirits and the murder of infants whose sucked blood was used, together with other ingredients, for the unguent that allowed them to ride through the air-to the walnut tree of Benevento. Yet even though the description of this assembly of numerous witches seems to provide a nascent view of the witches' Sabbath, a dance does not seem to feature in the trial testimony. ${ }^{25}$

In most fifteenth-century works concerned with witchcraft, there is little detailed description of dancing. Typical is the reference to dancing in a 1460 account of the diabolical 'synagogue' of Waldensian witches in Lyons. While this includes a description of the rituals involving idolatry, the desecration of Christian objects, the preparation of powders and unguents, and the sexual copulation with devils and each other, the only reference to dancing is that 'immediately after paying homage [to the Devil], they begin to dance to the sound of a soft buccin [a form of trombone] or a bagpipe'. ${ }^{26}$ A 1460 account of the Waldensian heretics of Arras by an anonymous author, most probably Jacques du Bois, the dean of the Arras cathedral chapter, is similar, referring only to the dances (tripudia) that initiates at witches' meetings sometimes attended and that were accompanied by stringed instruments and drums. ${ }^{27}$ Later tracts on witchcraft, such as by the Master of the Sacred Palace, Sylvester Mazzolini Prieras, the Dominican Inquisitor of Modena, Bartolomeo Spina, and the Dominican Inquisitor of Como, Bernard of Como, likewise refer to witnesses who have observed dancing as part of the witches' meeting or 'game' (ludus); but apart from the large number of dancers, they provide no details. $^{28}$

A significant exception is the Treatise on Heretics and Sorcerers by Paolo Grillando, originally written c.1524 and then printed in Lyons in 1536, 1545, and 1547, in Rome in 1581, and in Frankfurt in $1592 .^{29}$ The widespread influence of Grillando's work is clear from its many editions, and it was cited extensively later in the century by Jean Bodin. Grillando was a doctor of both canon and civil law, served as a judge in the vicinity of Rome, and heard criminal cases in Arezzo for the papal vicar, Andrea di Giacomo. His information concerning witches' dances came from reports he had heard of an unnamed male peasant from a village near Rome who accompanied his wife to the 'game' (ludum) after he noticed she kept disappearing from their bed each night; the report of a sixteen-year-old village girl from the same Sabine region, who had been seduced by a witch and 
was carried to their assembly; and from his own investigation in September 1524, of two women who had been imprisoned as witches in the Castle Nazzano, just north of Rome, by the Abbot of the monastery of San Paolo de Urbe in nearby Civitella San Paolo. ${ }^{30}$

All these reports expressed amazement at the large numbers of men and women who engaged in dancing and singing to the sweet sounds of cymbals, tympani, and other instruments at these meetings - at one point called the 'Benevento games'. 31 The dances were a tripudium, with suggestions of a ritualized liturgical dance, a $c(h)$ orrea, a ring dance, and a saltatio, a leaping dance-and they were performed backwards, 'against the custom of nature and the order of such dances'. ${ }^{32}$ Informants referred to the captivating pleasures, immense joy, and delirious delight of the games and the magnificent power of the dances performed with great exuberance and charm. ${ }^{33}$ They occurred after homage had been paid to Satan and before all sat down to the feast, which was followed in turn by sexual coupling with the devils.

The accounts of witches' dances in Grillando's work are radically different to the other ceremonies described in considerable detail in this and most earlier works on witchcraft. Those ceremonies describe the rituals of induction into a congregation of witches in great detail. Initiates are referred to as making either solemn public or private profession, in the manner of novices entering a religious order, who make a profession of their vows before being accepted as full members. The witch novices abjure God and the sacraments, they adore and pay homage to the Devil, offer prayers and sacrifices, engage in sexual union with the Devil and the congregation's other members, and are finally given their particular evil commissions to go out into the wider world and wreak destruction in the name of their master, Satan. By contrast, the dances that feature in the stories provided by village women and girls are clearly based on popular traditions. In the case of Grillando's work, they are stories related to the walnut tree of Benevento, which have been grafted on to claims about a congregation of witches, modelled on inverted and utterly perverse monastic structures, rituals, and community. But these stories offer a first hint of alternative forms of association by witches, modelled more on their own bodies and dispositions than on hierarchical institutional structures.

Perhaps it was the wide circulation of stories of the 'Benevento games' in Grillando's work in the late 1530s and 1540s that influenced this undated drawing of the witches of Benevento by the Italian sculptor and stucco designer, Guglielmo della Porta, created sometime between the mid-1530s and his death in 1577 (Figure 11.7). The dancing witches on the right, their nakedness showing through flowing dresses that further accentuate their jagged movements, convey well the discordance of these dances, while the walnut tree at centre appears almost alive in its wildness, seeming to welcome the women arriving at the games. No other depiction of such events from the sixteenth century seems to have survived. Della Porta moved to Rome in 1537, created some of his major works in the city (such as the tomb of Pope Paul III in St Peter's 
Basilica), and was also appointed to the papal mint in 1547 . He certainly moved in the right circles to hear of the stories of witches' dances that emanated from Latium and the Sabine hills, and the current discussions of witchcraft by Roman theologians such as Bartolomeo della Spina.

The widespread influence of Grillando's work, including his accounts of dances at Benevento, is clear from a reading of the most influential treatise on witchcraft in the later sixteenth century, On the Demon-Mania of Witches (1580), by the French jurist and political philosopher, Jean Bodin. ${ }^{34}$ Book II, chapter 4 of this work, which ran into twenty editions, including translations into Latin, German, and Italian by 1602, considers the renunciation of God and the Christian faith by witches, and how the Devil marks them publicly as his devotees. There Bodin cites Grillando's story of the peasant couple from a village near Rome who saw a huge number of men and women dancing in a circle, back to back with their faces facing outward. ${ }^{35} \mathrm{He}$ also tells the story of Grillando's sixteen-year-old village girl (here she is thirteen), who was taken by an older witch to a witches' meeting, as well as that of the woman from the castle of Nazzano, who joyfully danced at Benevento and had sex with the Devil before being transported back home. ${ }^{36}$ But as well as the Benevento walnut tree as the location for these witches' dances, Bodin argues on the basis of other French examples, that such dances also take place at local village crosses, sometimes also at a cross road. ${ }^{37}$ Most other references to dancing in Bodin's work, such as the examples drawn from the works of Lambert Daneau and Joachim Camerarius, are mere mentions without further elaboration, simply listing dancing as a component of witches' meetings. But there is one significant exception-evidence from a witches' meeting held near Logny (in Laon), in which six witches renounced God, kissed their devils, then danced with their brooms in their hands.

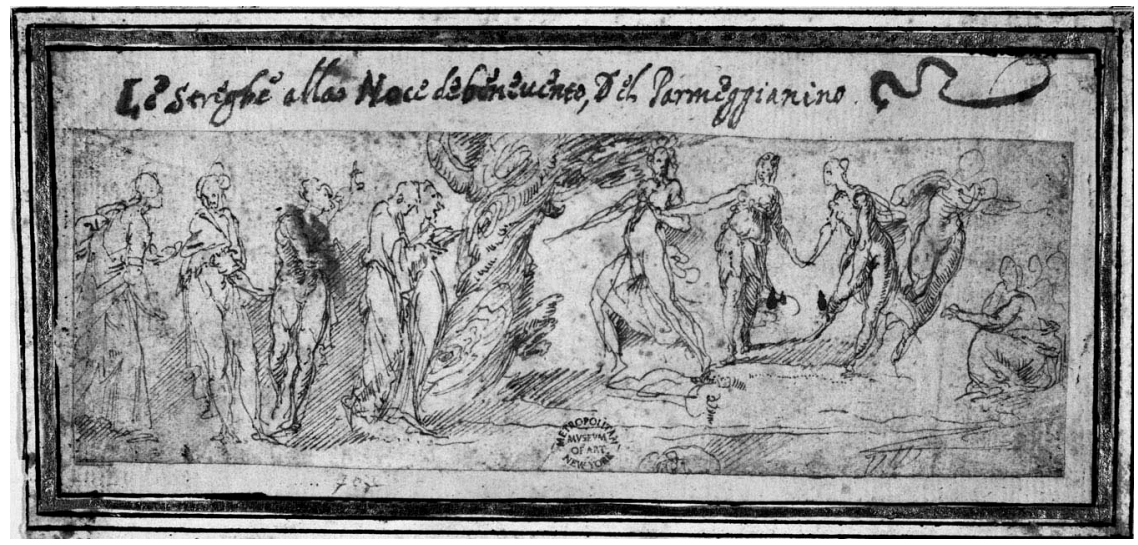

FIGURE 11.7 Guglielmo della Porta, The Witches at the Walnut Tree of Benevento, 1534-1577, pen \& brown ink, $6 \times 18.1 \mathrm{~cm}$. Metropolitan Museum of Art, Gift of Cephas G. Thompson, 1887, Accession No. 87.12.37. Public Domain. 
[And] while dancing they would cry 'Har, har, Devil, Devil, jump here, jump there, play here, play there.' And the others would chant, 'sabbath, sabbath,' that is to say, the feast and day of rest, raising their hands and brooms up high to testify and give a sure witness of gladness and that they willingly serve and worship the devil-and also to mimic the worship of God. $^{38}$

Significantly, writes Bodin, whenever these witches hold an assembly, they always dance.

This claim seems to prompt Bodin to suggest a number of possible explanations for these dances. Firstly, dancing expresses the joy and happiness of the devotee, ${ }^{39}$ the movements of the body raising the heart-just as the Jews danced when they brought sacrifices to the Temple, as the prophets of Samuel danced when Saul was chosen king, as David danced before the Ark of the Covenant, or as many ancient peoples danced during their sacred sacrifices and festivals. Secondly, and by contrast, witches' dances 'make men frenzied and women abort'. ${ }^{40}$ In support, Bodin claims that the insolent and lascivious movements of La volta - a spinning dance that involves a close and intimate hold between a couple, with the woman being lifted into the air assisted by the thigh of the male, while the couple turns 270 degrees-was brought by witches to France from Italy and has caused numerous murders and abortions. Thirdly, Bodin suggests that dancing is a form of provocation by the Devil against Christian states. In support, he cites the report of a young girl in Geneva who made everyone dance after touching them with an iron wand she had received from the Devil - and she did this because 'the city of Geneva hates dances more than anything. ${ }^{41}$ Fourthly, this frenzied dancing might well have the same cause as those who suffer from St Vitus' dance or who are mad. For, Bodin claims, they also engage in the same kind of dances and 'violent leaps', and are only cured by being made to dance to a very slow rhythm. ${ }^{42}$

Bodin also makes a clear distinction between holy and diabolical dances. Although diabolical dances are certainly performed to mimic the godly, instilling and demonstrating devotion and loyalty, a range of additional emotions motivate the dancers, and these lead to quite different outcomes. Witches' dances are stimulated by sexual desire and a frenzy associated with madness; they generate further frenzy in turn, which leads to murder and miscarriages. Moreover, as Bodin states very clearly, these dances are therefore not only a threat to the moral order, but 'a matter of the highest consequence for a state' ${ }^{43}$ By his suggestion that the Devil promotes dancing in Geneva because this society hates dancing so much, he ratchets up the threat that witches' dances pose for society as a whole. As we have already seen, the dancing of witches was linked in visual and literary sources with sexual desire. Bodin builds on such links by identifying witches as those who brought the volta to France. But he also links dances to the disordered passions of those who 
suffer from derangement and dancing mania. Furthermore, he emphasizes that in some locations at least, like Longny, dancing is an integral and identifiable component in witches' meetings.

Many of Bodin's claims about witches' dances were further developed by Nicolas Remy, privy councillor to Duke Charles III of Lorraine from 1575, supervisory judge at the ducal court in Nancy from 1576 to 1591, and chief prosecutor of Lorraine until $1606 .^{44}$ In 1595 Remy published Demonolatry, an influential work that was reprinted in Cologne and Frankfurt in 1596, in Frankfurt again in 1597, and in German translation in Frankfurt in 1598. ${ }^{45}$ The work drew on a large number of trials in the Lorraine-but contrary to Remy's claim, on only a few of those over which he himself had presided-as well as classical and more recent demonological literature. ${ }^{46}$ Remy's description of the 'nocturnal synagogues' of witches and their dances (primarily found in Book 1, chapters 14, 17, and 19) is certainly the most comprehensive treatment of the subject to that time. It draws considerably on Jean Bodin, and likewise emphasizes the 'uncommon' manner of the back-to-back ring dances, serving to confirm this as fact by reference to evidence provided by no less than eight different witnesses in recent trials. ${ }^{47}$ Remy is unsure whether this is the result of individuals not wishing to be recognized by others if they happen to be accused; whether they simply love everything that is absurd and unseemly; or (as he suggests when relating a story in which such dances are called 'preposterous' and 'ridiculous') this is the behaviour of 'a stupid and deranged crowd' ${ }^{48}$ As he concludes very significantly: the inverted gestures they insert into their rituals and backward dancing is 'most alien to all the behaviour of other humans'. ${ }^{49}$ These dances clearly demonstrate how alien witches are to the rest of society, and this is further underwritten by the fact that dancing leads to sin, either to lust and vice or to fanatical frenzy and madness. ${ }^{50}$ Such claims are already found in Bodin; but with Remy they are far clearer, more pronounced, and insistent.

Remy moves well beyond Bodin's account of witches' dances, however, in three fundamental ways. Firstly, by drawing on a wide range of examples from ancient history, he argues that there is historical continuity between the witches' dances in the present and the worship of demons in the ancient past. It was the pagans who cultivated dancing-Greeks, Romans, Phoenecians, Druids-encouraged by demons who saw this as a way of inclining humans to sin. A complementary and defining example is that of the Israelites, who turned to idolatry and 'danced in a ring around the calf which was molten from their golden trinkets'. The witches' dances of the present are direct extensions of these ceremonies in pre-Christian times, a form of dancing maintained by demons in witches' secret assemblies. ${ }^{51}$ The second critical new claim made by Remy is 'that no one may be excused from dancing'. Remy refers to this as 'the most pitiable and unjust condition' imposed on witches, given dancing's wide-ranging and deleterious effects. Any who plead to not take part, because of sickness or age, are immediately subjected to violent 
beatings. ${ }^{52}$ While Bodin made a similar claim for particular regional assemblies, such as that in Laon, Remy is claiming it to be universal, to be true for all witches' assemblies. So for Remy, witches' dances not only have a long history stretching back to the ancients; they are also an integral part of all witches' assemblies in the present. In this way the relevance of witches' dances is established, and their potential threat becomes more widely applicable and more urgent.

The third innovation Remy brings to his account of witches' dances is a much stronger sense of the bodily experience of dancing - the movement of multiple rather than just single bodies, their gestures and sounds, the music to which bodies respond, the emotions they release, the different social purposes dances serve. Perhaps Remy was stimulated by Bodin's account of the movement and cries of the witches' dances at Laon. But he comes to his subject through an appreciation of the emotional power of music: as music affects the mind in different ways, he argues, to dampen or stimulate spirits, or to drive individuals to frenzy, so the sounds of trumpets and drums, human shouts and cries, the leaping of bodies and beating of shields were used by the Lacedaemonians and Batavians when going into battle or by the priests of Cybele and devotees of Bacchus when performing their rituals. This explains the discordant sounds and frenzied movements of witches and demons in their dances: 'harsh and discordant sounds have the power to drive and goad even the most peaceable to a frenzy', just as drums, trumpets, and shouts accompanied those about to enter the danger of battle, 'whetting their warriors' zeal with shouts and trumpets. ${ }^{, 53}$ Since witches' dances might be viewed as preambles to battle, Remy also focuses on the dark side of zeal, the dampening or even eradication, of human kindness:

Now there must be, at the witches' night meetings, some similar music of a kind to exclude from them all human kindness (if they are at all touched by it). For it is agreed that they leave [these meetings] raging like animals and as though inflamed by madness, the more ready and eager to compass the downfall and destruction of the human race, which is the Demons' one purpose and intention. Therefore all is done to a marvelous medley and confusion of noises, and it is beyond the power of words to describe the uncouth, absurd and discordant sounds that are uttered there. ${ }^{54}$

Even though Remy makes no mention of it, he was most likely conscious of the common, though not universal, view among writers on witchcraft, that witches could not shed tears, that they did not feel compassion. ${ }^{55}$ Here he seems to be identifying the performance of the witches' dance as a form of communal training that served to remove and replace emotions such as compassion that were central to Christian experience. Remy has recognized what has become a common claim in recent history of emotions research, that emotions are learnt through regular routinized practice, and especially through communal performance. ${ }^{56}$ But given the aim of this dance to create 
a community of witches imbued with a zeal that eradicates the compassion required of Christians and whose ultimate aim is to destroy Christian society, the performance of the dance also marks out this community of witches as totally other-a politically, intellectually, and emotionally alternative society, or more correctly, a counter-society.

With Remy's publication of Demonolatry in the 1590s, the witches' dance had become part of a long history of Devil-worship from ancient times and an integral component of all witches' meetings, displaying the frenzied and lascivious nature of witches as well as their hardened and merciless zeal in creating evil and instilling terror so as to ultimately destroy Christian communities. Two subsequent publications, important for their visual imagery, followed in Remy's footsteps. Francesco Maria Guazzo's Compendium Maleficarum of 1608 largely restated the claims found in Remy and drew examples from Bodin as well. ${ }^{57}$ Pierre de Lancre expanded on the examples provided by Remy by including others from both ancient and contemporary Basque societies, and in addition to the more familiar tropes of dancing as sexual foreplay, he developed further Remy's notion of witches' dances as communal performances in preparation for war. $^{58}$

In visual media there were parallel developments. In 1593, a woodcut previously used in the 1567 edition of Olaus Magnus' History of the Northern Peoples - and modelled on an earlier version in the first edition of 1555became the new title-page woodcut for the third Basel edition of a work attacking witchcraft persecution, Christian Thoughts and Reflections on Witchcraft, by the Heidelberg Professor of Greek and Mathematics at the University of Heidelberg, Hermann Witekind (Figure 11.8). ${ }^{59}$ The original 1555 woodcut illustrated belief in the nocturnal dance of the elves in Scandinavian folklore, while the 1567 Basel version presented a diabolized version, in which the satyr figures were now quite demonic and two of them were shown dancing with female partners (Figure 11.9). There is little doubt that the printer who published the 1593 edition of Witekind's work, Sebastian Henricpetri, used the woodcut he received from his father precisely because it could be viewed as a depiction of a witches' dance at a Sabbath under the guidance of Satan and his two assistants.

More importantly, in 1593 another unknown artist depicted for the very first time a massed assembly of witches at a supposed Sabbath in the electoral principality of Trier, which featured at its centre a wild and uninhibited witches' dance led by a demon (Figure 11.10). ${ }^{60}$ The print depicts numerous witches engaged in activities associated with the Sabbath: feasting and drinking, processing behind a witch mounted on the cadaver of a horse, consulting instructions in magic books, rubbing the bodies of those about to ride through the air, performing different magics around a cauldron, invoking spirits from a magic circle, and preparing to ride up chimneys to release the storms and fires depicted in the background. Sexuality is pervasive in this print, as are the signs and symbols of death, and 


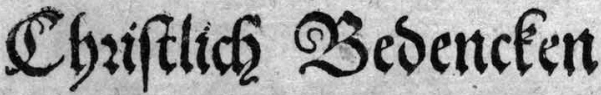 vnind cxinnceung vott \\ 3atberey/}

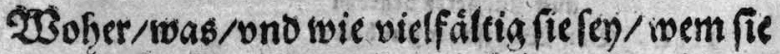

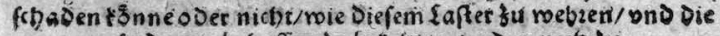
fo Damit behafic/iou betehien/ ODer auth ba friaffen festn.

\section{Befditeben ourd}

2luguftin Rerd)eimer vort Ereinfelden. Aut afentire bis, aut meliora doce.

Seß̧unb auffs netw gemstgret und nebeffort.

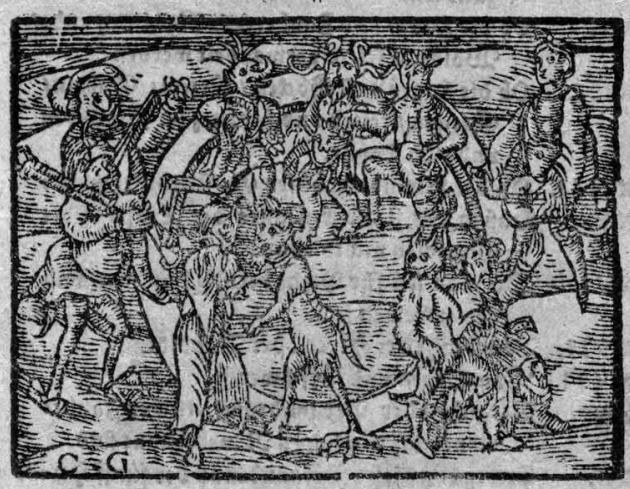

\section{Getrudit 3u 23ajel/ \\ Eebaftianum Şenricpetri.}

FIGURE 11.8 Title-page engraving of Augustine Lerchheimer [Hermann Witekind], Christlich Bedenken unnd Erinnerung von Zauberey (Basel: Sebastian Henricpetri, 1593). Cornell University Library, Witchcraft BF1583.A2 W82 1593 Text. Public Domain.

frantic magical activity. The artist has drawn on motifs and details from Pieter Bruegel the Elder in particular, but the quite novel element and visual focus of the print is the central cameo of the dance around a column, on top of which the Devil sits in the form of a toad. The dancers-several of them naked, and accompanied by death and an animal demon-fling up their arms and kick up their legs to the sound of the trumpeters behind. It is a wild and lewd dance, but also an idolatrous one, 


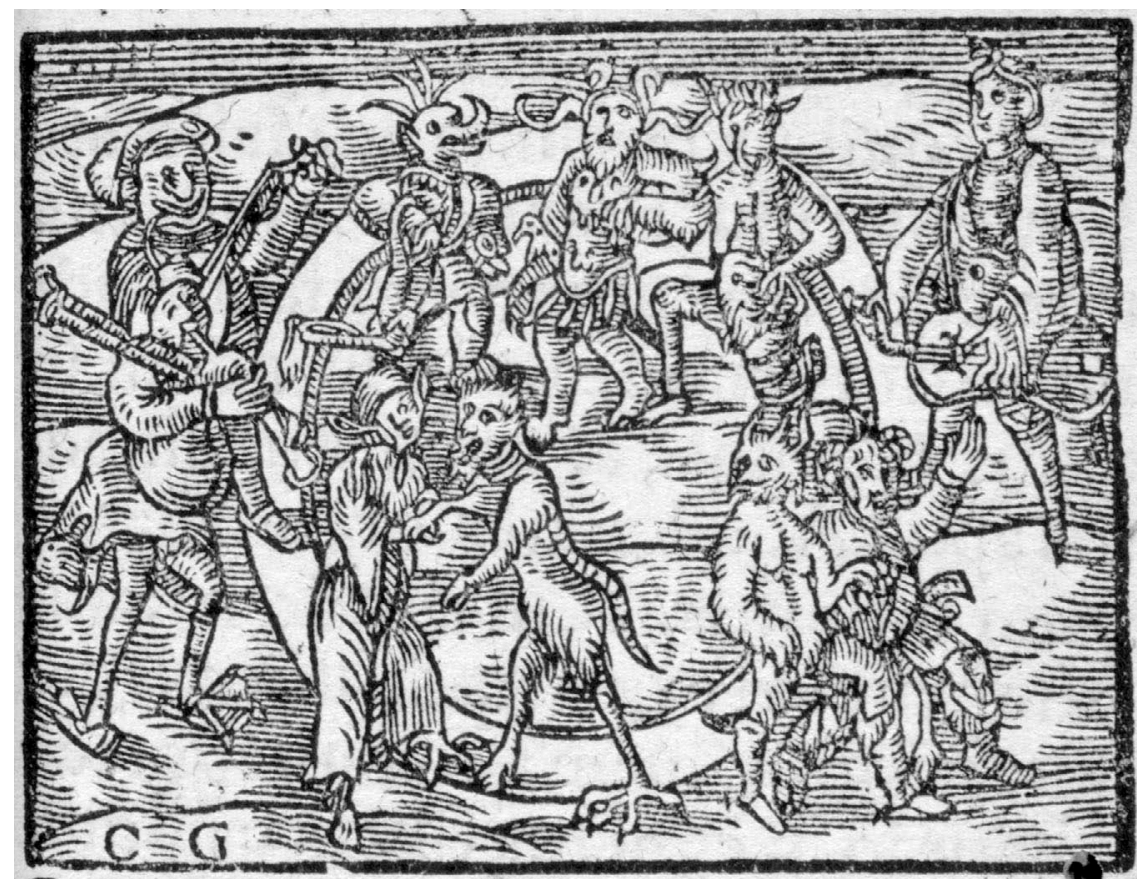

FIGURE 11.9 Master CG, The nocturnal dance of elves and demons, woodcut, in Olaus Magnus, Historia de Gentium Septentrionalium (Basel: Adam Henricpetri, 1567), 107. Cornell University Library, RMC2006_0172. Public Domain.

clearly modelled on images of the Israelites dancing around the golden calf. ${ }^{61}$ The dance has now become central in a complex scene of witchcraft, creating an axis with the cauldron, the most common code for witchcraft in the previous century. It is not yet the mass phenomenon depicted in the later print of Matthäus Merian (Figures $11.1 \& 11.2$ ), but it already provides clear visual evidence of witches as members of a diabolical community-united not only in their idolatry and loyalty to their god, but also in their uncontrolled lust, the way their sensual desires are being given free reign. Wild movement, discordant sounds, and accentuated gestures point to the destruction and ruin behind.

Through the seventeenth-century images of witchcraft with dancing at their centre become almost standard, shaped and strengthened by elements imported from broader iconographies of dance, whether of New World natives, the peasantry or the court, the gods of mythology, ancient rites, or contemporary celebration. ${ }^{62}$ But for that to happen, dance had first to be established as a significant code for witchcraft by theorists such as Jean Bodin and Nicolas Remy. Only then could witches be depicted as members of a wholly alien society, whose bodily behaviour as well as uncontrolled lust, uninhibited frenzy, and hardened zeal would bring their true nature and the threat they posed into much sharper public view. 


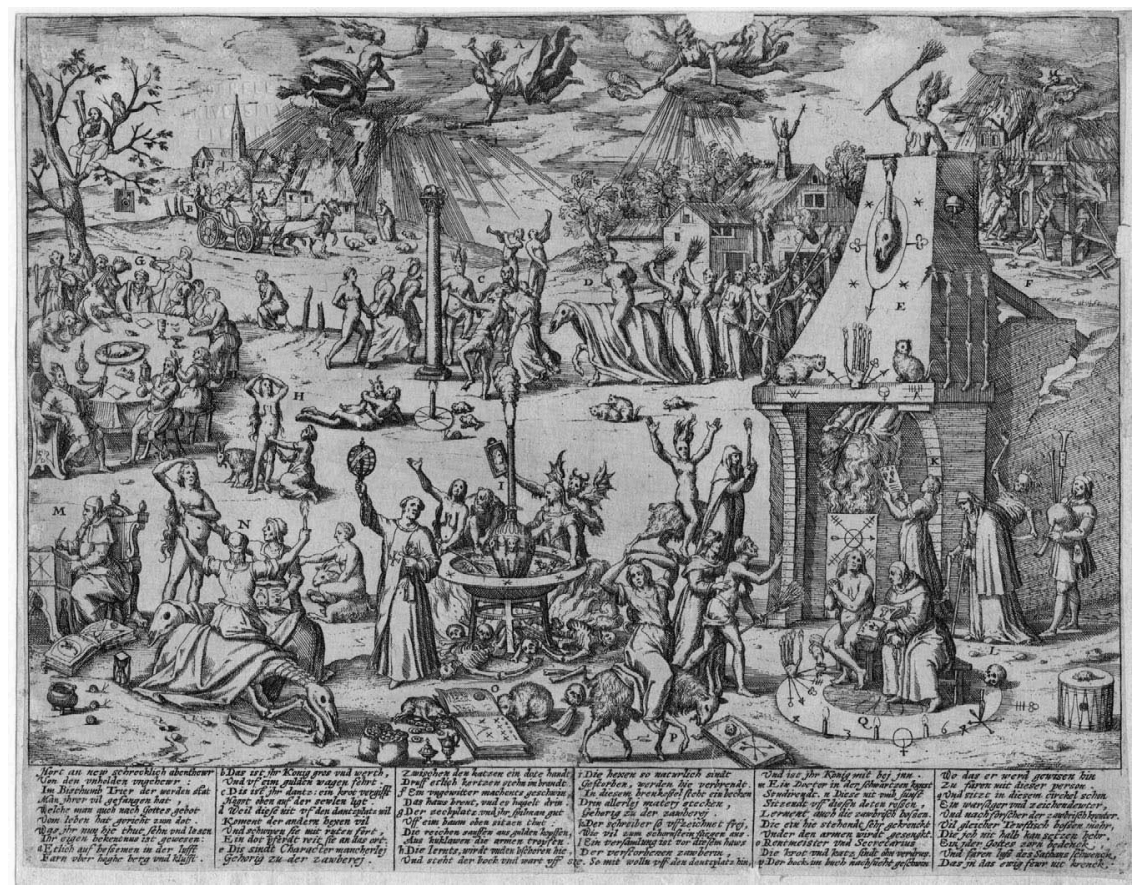

FIGURE 11.10 The so-called witches' Sabbath in Trier, engraving, in Thomas Sigfrid, Richtige Antwort auff die Frage: ob die Zeuberer und Zeuberin mit ihrem zauber Pulfer, Kranckheiten, oder den Todt selber beybringen können..., (Erfurt, 1593). Cornell University Library, RMC2015_0250. Public Domain.

\section{Notes}

1 For some recent examples, see Laura Kounine, Imagining the Witch: Emotions, Gender, and Selfhood in Early Modern Germany (Oxford: Oxford University Press, 2019); Charlotte-Rose Millar, Witchcraft, the Devil, and Emotions in Early Modern England (London: Routledge, 2017); Laura Kounine and Michael Ostling, eds, Emotions in the History of Witchcraft (London: Palgrave Macmillan, 2016); Lyndal Roper, The Witch in the Western Imagination (Charlottesville VA: University of Virginia Press, 2012), esp. chap. 4.

2 I have attempted to explore such techniques in a number of recent essays: "Emotions, Exclusion and Witchcraft Imagery," in The Routledge History of Emotions in Europe 1100-1700, ed. Susan Broomhall and Andrew Lynch, (London; New York: Routledge, 2020), 233-55; Zika, "The Transformation of Sabbath Rituals," in Emotion, Ritual and Power in Europe, 1200-1920: Family, State and Church, ed. Merridee L. Bailey and Katie Barclay (London: Palgrave Macmillan, 2017), 261-84; Zika, "The Cruelty of Witchcraft: The Drawings of Jacques de Gheyn the Younger," in Emotions in the History of Witchcraft, ed. Laura Kounine and Michael Ostling (London: Palgrave Macmillan, 2016), 37-56.

3 Brian P. Levack, The Witch-Hunt in Early Modern Europe, 4th ed. (Abingdon, Oxon.; New York: Routledge, 2016), 29-56.

4 Richard M. Golden, ed., Encyclopedia of Witchcraft: The Western Tradition, 4 vols. (Santa Barbara, Calif.: ABC-CLIO, 2006). 
5 Tilman Falk, ed., Hollstein's German Engravings, Etchings and Woodcuts 1400-1700, vol. 26. Matthaeus Merian the Elder (Ouderkerk aan den Ijssel: Sound \& Vision, 1989), 156-57; Lucas Heinrich Wüthrich, Das druckgraphische Werk von Matthäus Merian d. Ä., vol.1. Einzelblätter und Blattfolgen (Basel: Bärenreiter, 1966), 161-62. For Herr, see Silke Gatenbröker, Michael Herr (1591-1661): Beiträge zur Kunstgeschichte Nürnbergs im 17. Jahrhundert; mit Werkverzeichnis (Münster: Lit Verlag, 1996) (and for this broadsheet, 56-58, 606-9). For the later influence of the print see Charles Zika, "The Witch and Magician in European Art," in The Oxford Illustrated History of Witchcraft and Magic, ed. Owen Davies (Oxford: Oxford University Press, 2017), 153-54.

6 For discussion and further literature on the broadsheet's unclear dating history, and the disputed identity of Claj, see Doris Gruber, "Der Hexensabbat: Zeitgenössische Darstellungen auf illustrierten Flugblättern" (M.Phil. thesis, Karl-FranzensUniversität, Graz, 2013), 50-71; Thomas DaCosta Kaufmann, Central European Drawings in the Collection of the Crocker Art Museum (Turnhout: Brepols, 2004), 480.

7 For scenes of witchcraft by these artists, see Linda C. Hults, The Witch as Muse: Art, Gender, and Power in Early Modern Europe (Philadelphia: The University of Pennsylvania Press, 2005), 109-44; Ursula Härting, Frans Francken der Jüngere (1581-1642): die Gemälde mit kritischem Oeuvrekatalog (Freren: Luca, 1989), 68-71, 360-62; Zika, "The Cruelty of Witchcraft," 45-46; Zika, "The Transformation of Sabbath Rituals," 268-74; Judith Venjakob, Der Hexenflug in der frühneuzeitlichen Druckgrafik: Entstehung, Rezeption und Symbolik eines Bildtypus (Petersberg: Michael Imhof, 2016), 225-30.

8 One is in the Crocker Art Museum, Sacramento, the other in the Staatlichen Museen, Berlin. See William Breazeale, with Cara Denison, Stacey Sell, and Freyda Spira, A Pioneering Collection: Master Drawings from the Crocker Art Museum (London: Paul Holberton Publishing; Sacramento, CA: Crocker Art Museum, 2010), 134-35; Gatenbröker, Michael Herr, 57, 100, 243 (no. Z47); Kaufmann, Central European Drawings, 47-49.

9 Stories of the Blocksberg primarily circulated in northern Germany and featured in many trials in the Rostock area from the 1570s, as well as in the works of the lawyer, Johann Georg Gödelmann, Von Zäuberern, Hexen und Unholden (Frankfurt am Main, 1592), and the journalist, Heinrich Kornmann, Mons Veneris, Fraw Veneris Berg (Frankfurt am Main, 1614).

10 This and other figures in the billowing smoke have recently been interpreted as representations of the 'fall' of the witches, in the manner of Simon Magus. See Judith Venjakob, Der Hexenflug, 221-24.

11 'Sieh an O Leser dieses Bild/So schröcklich seltzam wüst und wild'.

12 For some examples, Charles Zika, "Recalibrating Witchcraft Through Recycling," in The Primacy of the Image in Northern European Art, 1400-1700 ed. Debra Cashion, Henry Luttikhuizen and Ashley West (Leiden and Boston: Brill, 2017), 394-98; Zika, "Emotions, Exclusion and Witchcraft Imagery," 249-52.

13 Renilde Vervoort, Bruegel's Witches: Witchcraft Images in the Low Countries Between 1450 and 1700, trans. Paul and Gregory Arblaster (Bruges: Van de Wiele, 2015), 62-68; The Arras Witch Treatises, ed. Andrew Gow, Robert Desjardins, and François Pageau (University Park, PA: The Pennsylvania State University Press, 2016).

14 Vervoort, Bruegel's Witches, 62-68; Charles Zika, The Appearance of Witchcraft: Print and Visual Culture in Sixteenth-Century Europe (London and New York: Routledge, 2007), 65-66.

15 Joseph Hansen, Quellen und Untersuchungen zur Geschichte des Hexenwahns und der Hexenverfolgung im Mittelalter (Hildesheim: G. Olms, 1963), 102, 1. 27: 'Aux aultres les danses plaisoient'. Also see Martine Osterero, Agostino Paravicini Bagliani, Kathrin Utz Tremp and Catherine Chène, eds, L'Imaginaire du sabbat. Edition critique des textes les plus anciens (1430c.-1440c.) (Lausanne: Université de Lausanne, 1999), 456, 1. 17,477. A second mention of witches dancing $(458,1.17,542)$ connects it to jubilation. 
16 Hans Vintler, "Buch der Tugend," Gotha, c.1500, fol. 37r; and Vienna, c.1400-1450, fol. 59r. For Vintler, Zika, Appearance of Witchcraft, 39-46.

17 Ulrich Molitor, De laniis et phitonicis mulieribus Teutonice Unholden vel Hexen (Reutlingen, after 1489). For a list of the editions, see Nancy Kwan, "Woodcuts and Witches: Ulrich Molitor's De lamiis et pythonicis mulieribus, 1489-1669," German History 30, no.4 (2012): 524-25. Also Zika, Appearance of Witchcraft, 18-27.

18 Grant danse macabre des femmes (Paris, 1491); La grant danse macabre des femmes hystoiriée (Paris, 1499); "Danse Macabre des Femmes" (c.1500), Bibliothèque Nationale de France, Ms fr. 995. See Zika, Appearance of Witchcraft, 21, 239 n34.

19 See Charles Zika, "Visual Signs of Imminent Disaster in the Sixteenth-Century Zurich Archive of Johann Jakob Wick," in Disaster as Image: Iconographies and Media Strategies across Europe and Asia, ed. Monica Juneja and Gerrit Jasper Schenk (Regensburg: Schnell und Steiner, 2014), 43-53, 217-20.

20 Johann Jakob Wick, "Sammlung von Nachrichten zur Zeitgeschichte aus den Jahren 1560-87," Zentralbibliothek Zürich (hereafter ZBZ), Wickiana, F. 18, fols. 145r46v. See also Zika, Appearance of Witchcraft, 200-202.

21 Colin Slim claims that the hand and feet positions of the dancers and the musicians suggest a basse dance: Slim, "Mary Magdalene, Musician and Dancer," Early Music 8 (1980), 462-65. Also see Peter Parshall, "Lucas van Leyden's narrative style," Nederlands Kunsthistorisch Jaarboek 29 (1978): 223-29. For Magdalen dancing with Lucifer and demons, see "The Alsfeld Passion Play," in Das Drama des Mittelalters. Die Lateinischen Osterfeiern und ihre Entwicklung in Deutschland, ed. Richard Froning (Darmstadt: Wissenschaftliche Buchgesellschaft, 1964), 630-33, 1. 1770-853.

22 For this trial and execution, which also included that of Verena Trostin, see ZBZ, Wickiana, F. 23, fols. 399-422; Zika, Appearance of Witchcraft, 196-97, 201-6, fig. 7.12 .

23 Paolo Portone, "Benevento, Walnut Tree of," in Golden, Encyclopedia of Witchcraft, 1:109-10; Franco Mormando, The Preacher's Demons: Bernardino of Siena and the Social Underworld of Early Renaissance Italy (Chicago: University of Chicago Press, 1999), 61-67.

24 Mormando, The Preacher's Demons, 67-68.

25 For this case, Domenico Mammoli, The Record of the Trial and Condemnation of a Witch, Matteuccia di Francesco at Todi, 20 March 1428 (Rome: n.p., 1972); Candida Peruzzi, "Un processo di stregoneria a Todi nel '400," Lares 21, no.1-2 (1955): 1-17. Also Richard Kieckhefer, European Witch Trials: Their Foundations in Popular and Learned Culture, 1300-1500 (London: Routledge and Kegan Paul, 1976), 73-74; Mormando, The Preacher's Demons, 72-77.

26 "La Vauderye de Lyonois en brief," in Hansen, Quellen, 191: 'Item, in ipsa convencione, statim facto homagio, ut premissum est, coreizare incipient ad sonum cuiusdam surde bucine seu musete.' For this work in the broader context of Waldensianism, see Wolfgang Behringer, "Vaudois (Waldensians)," in Golden, Encyclopedia of Witchcraft, 4:1160-66.

27 "Recollectio casus, status et condicionis Valdensium ydolatrarum," in Hansen, Quellen, 162; Gow, The Arras Witch Treatises, 42-43.

28 Sylvester Mazzolini, De Strigimagarum daemnumque mirandis (Rome, 1521), 136; Bartolomeo della Spina, Quaestio de Strigibus (Rome, 1576; first edition [Venice], 1523), 49-50, 58; Bernard of Como, De Strigiis, in Lucerna inquisitorum haereticae praevitatis et tractatus de strigibus (Rome, 1584), 143. This last work was written c.1508 and first published in Milan, 1566.

29 Paolo Grillando, Tractatus de hereticis et sortilegiis ... (Lyons, 1536). For Grillando, see Drie Vanysacker, "Grillando (Grillandus), Paolo (Paulus) (1st Half 16th Century)," in Golden, Encyclopedia of Witchcraft, 1:459-60. 
30 Grillando, Tractatus, fols. 39v-43r; Hansen, Quellen, 340-41; Henry Charles Lea, Materials Toward a History of Witchcraft, ed. Arthur C. Howland, 3 vols (Philadelphia: University of Pennsylvania Press, 1939), 1:403-5.

31 Grillando, Tractatus, fol. 43ra.

32 Grillando, Tractatus, fol. 40rb: 'ordine quodam retrograde contra morem naturae et ordinem corearum.'

33 Grillando, Tractatus, fols. 41ra, 42rb.

34 Jean Bodin, La Démonomanie des sorciers ... (Paris, 1580). For Bodin, see Rune Hagen, "Bodin, Jean (1529/1530-1596)," in Golden, Encyclopedia of Witchcraft, 1:129-31; Jonathan L. Pearl, The Crime of Crimes: Demonology and Politics in France, 1560-1620 (Waterloo, Ontario: Wilfrid Laurier University Press, 1999), 110-26.

35 Bodin, Démonomanie, fol. 82v: 'une danse en rond les faces tournees hors le rondeau'; Jean Bodin, On the Demon-Mania of Witches, trans. Randy A. Scott, intro. Jonathan L. Pearl (Toronto: Centre for Reformation and Renaissance Studies, 1995), 115-16.

36 Bodin, Démonomanie, fols. $83 \mathrm{r}-84 \mathrm{v}$. These two cases are omitted from Randy Scott's abbreviated translation.

37 Bodin, Démonomanie, fols. 83v, 86v; Bodin, On the Demon-Mania, 116, 118. The description of these ceremonies and their dances is very similar to that of the Waldensian witches.

38 Bodin, Démonomanie, fols. 87v-88r; Bodin, On the Demon-Mania, 120.

39 Bodin, Démonomanie, fol. 88r: 'pour testifier et donner un certain tesmoignage d'allegresse, \& que de bon Coeur ils servent \& adorent le Diable'; Jean Bodin, De Magorum Daemonomania (Basel, 1581), 169: 'ut testificarentur certo quanta alacritate animi studioque colerunt diabolum atque adorarent.'

40 Bodin, Démonomanie, fol. 88r: 'rendent les hommes furieux, \& sont avorter les femmes.' Bodin, On the Demon-Mania, 120. The German translation by Johann Fischart translates 'furieux' as 'rasend und wütig' (frenzied and raging). See Jean Bodin, Vom aussgelasnen wütigen Teuffelsheer, Übersetzt von Johann Fischart (Graz: Akademische Druck- u. Verlagsanstalt, 1973), 111.

41 Bodin, On the Demon-Mania, 120; Bodin, Démonomanie, fol. 88v.

42 Bodin, Démonomanie, fol. 88v: 'tous les hommes furieux, \& forcenez usent de tells danses, \& sauts violens'; Bodin, De Magorum Daemonomania, 171: 'constat non alios quam furiosos \& vaesonos homines tripudiationibus istis \& \& [sic] saltationibus violentis uti'. Here the Latin is possibly more explicit in distinguishing between the more processional form of the tripudium and the leaping nature of the saltatio.

43 Bodin, De Magorum Daemonomania, 170: 'quod homicidia \& abortus innumeri ex ea accidunt: quod in republica in primis consyderari oportet, \& severissime prohiberi'; Bodin, Démonomanie, fol. 88v.

44 Robin Briggs, The Witches of Lorraine (Oxford: Oxford University Press, 2007), 20-23; William Monter and Edward Peters, "Rémy, Nicolas (ca.1530-1612)," in Golden, Encyclopedia of Witchcraft, 4:955-57.

45 Nicolas Remy, Daemonolatria (Lyons, 1595). See Kounine, Imagining the Witch, 198-220. The work was very influential in the seventeenth century and appeared in at least eight further editions and translations.

46 Briggs, Witches of Lorraine, 48-50.

47 Remy, Daemonolatria, 134; Nicolas Remy, Demonolatry, ed. Montague Summers, trans. E. A. Ashwin (Secaucus, N.J.: University Books, 1974), 61. See also the following note.

48 Remy, Daemonolatria, 135, and 114: 'ac saltantium choreas oculis otiosus collustrat, forte rei insoletiam admiratus (nam praepostera, ridiculaque illic errant omnia) Deus bone (inquit) unde isthaec nobis tam stulta, amensque turba'; also 115: 'advertit in arvo finitimo chorum in orbem saltantium, tum virorum, tum mulierum: Verum quod praeter solitum aliorum hominum morem aversi, tergaque ostendentes id faciebant'. Remy, Demonolatry, 49-50, 61. 
49 Remy, Daemonolatria, 135: 'ab omni consuetudine reliquorum hominum alienissima'; Remy, Demonolatry, 61.

50 Remy, Daemonolatria, 135: 'vel ad luxuriam ac nequitiam ... vel ad fanaticos furors ac dementiam'; Remy, Demonolatry, 61. Ashwin incorrectly translates 'luxuriam' as 'luxury' in this passage.

51 Remy, Daemonolatria, 133-34; Remy, Demonolatry, 60.

52 Remy, Daemonolatria, 134; Remy, Demonolatry, 61.

53 Remy, Demonolatry, 64; Remy, Daemonolatria, 139-41.

54 Remy, Daemonolatria, 141: 'Horum autem simile aliquid intercedere oportet in sagarum nocturnis conventibus, quo ab humanitate omni, si quae illas forte adhuc tangit, deducantur. Nam illinc efferatas discedere convenit ac quasi rabie accensas: quo scilicet sint ad mortalium perniciem, exitumque (cui uni rei incumbent Daemones) instructiores, ac paratiores.' The translation is my adaptation of Ashwin's loose translation, which also omits some key phrases (see Remy, Demonolatry, 64).

55 Zika, "The Cruelty of Witchcraft," 46-49.

56 Monique Scheer, "Are Emotions a Kind of Practice (and Is That What Makes Them Have a History)?: A Bourdieuian Approach to Understanding Emotion," History and Theory 51 (2012), 193-220.

57 Francesco Maria Guazzo, Compendivm maleficarvm ... (Milan, 1608); Francesco Maria Guazzo, Compendium Maleficarum, ed. Montague Summers, trans. E. A. Ashwin (Secaucus, N.J.: University Books, 1974), especially book 1, chapter 12. The illustrations to Guazzo are in need of close analysis, but lie beyond the scope of this paper.

58 Pierre de Lancre, On the Inconstancy of Witches: Pierre de Lancre's Tableau de l'inconstance des mauvais anges et demons (1612), ed. Gerhild Scholz Williams, trans. Harriet Stone and Gerhild Scholz Williams (Tempe: Arizona Center for Medieval and Renaissance Studies; Turnhout: Brepols, 2006); and for Jan Ziarnko's illustration of de Lancre's Sabbath, Zika, "The Transformation of Sabbath Rituals," 266-74.

59 Witekind, born as Hermann Wilcken, published the book under a pseudonym Augustin Lercheimer, Christlich bendencken und erinnerung (Heidelberg, 1585).

60 For a detailed account of this work, Renata Voltmer, "'Hört an neu schrecklich abentheuer von den unholden ungeheuer': zur multimedialen Vermittlung des Fahndungsbildes 'Hexerei' im Kontext konfessioneller Polemik," in Repräsentationen von Kriminalität und öffentlicher Sicherheit: Bilder, Vorstellungen und Diskurse vom 16. bis zum 20. Jahrhundert, ed. Karl Härter, Gerhard Sälter and Eva Wiebel (Frankfurt am Main: V. Klostermann, 2010), 89-163.

61 Images of dancing around the golden calf become common in the sixteenth century, for as well as featuring in bibles, they are often used to illustrate the first commandment in catechisms, and also chapter 61 on dancing in the numerous editions of Sebastian Brant's Ship of Fools.

62 For recent exploration of such themes, see Alessandro Arcangeli, L'altro che danza: Il villano, il selvaggio, la Strega nell'immaginario della prima età moderna (Milan: Edizioni Unicopli, 2018).

\section{Bibliography}

Arcangeli, Alessandro. L'altro che danza: Il villano, il selvaggio, la Strega nell'immaginario della prima età moderna. Milan: Edizioni Unicopli, 2018.

Bernard of Como. De Strigiis. In Lucerna inquisitorum haereticae praevitatis et tractatus de strigibus. Rome, 1584.

Bodin, Jean. La Démonomanie des sorciers .... Paris, 1580.

Bodin, Jean. De Magorum Daemonomania. Basel, 1581.

Bodin, Jean. Vom aussgelasnen wütigen Teuffelsheer, Übersetzt von Johann Fischart. Graz: Akademische Druck u. Verlagsanstalt, 1973.

Bodin, Jean. On the Demon-Mania of Witches. Translated by Randy A. Scott, introduction by Jonathan L. Pearl. Toronto: Centre for Reformation and Renaissance Studies, 1995. 
Breazeale, William, with Cara Denison, Stacey Sell, and Freyda Spira. A Pioneering Collection: Master Drawings from the Crocker Art Museum. London: Paul Holberton Publishing; Sacramento, CA: Crocker Art Museum, 2010.

Briggs, Robin. The Witches of Lorraine. Oxford: Oxford University Press, 2007.

Erhardt, Michelle and Amy M. Morris, eds. Mary Magdalene, Iconographic Studies from the Middle Ages to the Baroque. Leiden: Brill, 2012.

Falk, Tilman, ed. Hollstein's German Engravings, Etchings and Woodcuts 1400-1700. Vol. 26, Matthaeus Merian the Elder. Ouderkerk aan den Ijssel: Sound \& Vision, 1989.

Froning, Richard, ed. Das Drama des Mittelalters. Die lateinischen Osterfeiern und ihre Entwicklung in Deutschland. Darmstadt: Wissenschaftliche Buchgesellschaft, 1964.

Gatenbröker, Silke. Michael Herr 1591-1661. Beiträge zur Kunstgeschichte Nürnbergs im 17. Jahrhundert: mit Werkverzeichnis. Münster: Lit Verlag, 1996.

Gödelmann, Johann Georg. Von Zäuberern, Hexen und Unholden. Frankfurt am Main, 1592.

Golden, Richard M., ed. Encyclopedia of Witchcraft: The Western Tradition. 4 vols. Santa Barbara, CA: ABC-CLIO, 2006.

Gow, Colin, Robert B. Desjardins, and François V. Pageau. Eds. The Arras Witch Treatises. University Park: The Pennsylvania State University Press, 2016.

Grant danse macabre des femmes. Paris, 1491.

Grillando, Paolo. Tractatus de hereticis et sortilegiis ... eorumque poenis. Lyons, 1536.

Gruber, Doris. "Der Hexensabbat: Zeitgenössische Darstellungen auf illustrierten Flugblättern.” M.Phil. thesis, Karl-Franzens-Universität, Graz, 2013.

Guazzo, Francesco Maria. Compendivm maleficarvm .... Milan, 1608.

Guazzo, Francesco Maria. Compendium Maleficarum. Edited by Montague Summers, translated by E. A. Ashwin. Secaucus, NJ: University Books, 1974.

Hansen, Joseph. Quellen und Untersuchungen zur Geschichte des Hexenwahns und der Hexenverfolgung im Mittelalter. Hildesheim: G. Olms 1963.

Härting, Ursula. Frans Francken der Jüngere 1581-1642: die Gemälde mit kritischem Oeuvrekatalog. Freren: Luca, 1989.

Hults, Linda C. The Witch as Muse: Art, Gender, and Power in Early Modern Europe. Philadelphia: University of Pennsylvania Press, 2005.

Kaufmann, Thomas DaCosta. Central European Drawings in the Collection of the Crocker Art Museum. Turnhout: Brepols, 2004.

Kieckhefer, Richard. European Witch Trials: Their Foundations in Popular and Learned Culture, 1300-1500. London: Routledge and Kegan Paul, 1976.

Kornmann, Heinrich. Mons Veneris, Fraw Veneris Berg. Frankfurt am Main, 1614.

Kounine, Laura. Imagining the Witch: Emotions, Gender, and Selfhood in Early Modern Germany. Oxford: Oxford University Press, 2019.

Kounine, Laura and Michael Ostling, eds. Emotions in the History of Witchcraft. London: Palgrave Macmillan, 2016.

Kwan, Nancy. "Woodcuts and Witches: Ulrich Molitor's De lamiis et pythonicis mulieribus, 1489-1669." German History 30, no.4 (2012): 493-527.

La grant danse macabre des femmes hystoiriée. Paris, 1499.

Lancre, Pierre de. On the Inconstancy of Witches: Pierre de Lancre's Tableau de l'inconstance des mauvais anges et demons (1612). Edited by Gerhild Scholz Williams, translated by Harriet Stone and Gerhild Scholz Williams. Tempe: Arizona Center for Medieval and Renaissance Studies; Turnhout: Brepols, 2006.

Lea, Henry Charles. Materials Toward a History of Witchcraft. Edited by Arthur C. Howland. 3 vols. Philadelphia: University of Pennsylvania Press, 1939.

Lercheimer, Augustin. Christlich bendencken und erinnerung. Heidelberg, 1585. 
Levack, Brian P. The Witch-Hunt in Early Modern Europe. 4th ed. Abingdon, Oxon; New York: Routledge, 2016.

Mammoli, Domenico. The Record of the Trial and Condemnation of a Witch, Matteuccia di Francesco at Todi, 20 March 1428. Rome: n.p., 1972.

Millar, Charlotte-Rose. Witchcraft, the Devil, and Emotions in Early Modern England. London: Routledge, 2017.

Molitor, Ulrich. De laniis et phitonicis mulieribus Teutonice Unholden vel Hexen. Reutlingen, after 1489.

Mormando, Franco. The Preacher's Demons: Bernardino of Siena and the Social Underworld of Early Renaissance Italy. Chicago: University of Chicago Press, 1999.

Osterero, Martine, Agostino Paravicini Bagliani, Kathrin Utz Tremp and Catherine Chène, eds. L'Imaginaire du sabbat. Edition critique des textes les plus anciens (1430c.-1440c.). Lausanne: Université de Lausanne, 1999.

Parshall, Peter. "Lucas van Leyden's narrative style." Nederlands Kunsthistorisch Jaarboek 29 (1978): 185-237.

Pearl, Jonathan L. The Crime of Crimes: Demonology and Politics in France, 1560-1620. Waterloo, ON: Wilfrid Laurier University Press, 1999.

Peruzzi, Candida. "Un processo di stregoneria a Todi nel '400.” Lares 21, no.1-2 (1955): $1-17$.

Reddy, William. The Navigation of Feeling: A Framework for the History of Emotions. New York: Cambridge University Press, 2001.

Remy, Nicolas. Daemonolatria. Lyons, 1595.

Remy, Nicolas. Demonolatry. Edited by Montague Summers, translated by E. A. Ashwin. Secaucus, NJ: University Books, 1974.

Roper, Lyndal. The Witch in the Western Imagination. Charlottesville VA: University of Virginia Press, 2012.

Scheer, Monique. "Are Emotions a Kind of Practice (And Is That What Makes Them Have a History)?: A Bourdieuian Approach to Understanding Emotion." History and Theory 51, no.2 (2012): 193-220.

Sigfrid, Thomas. Richtige Antwort auff die Frage: ob die Zeuberer und Zeuberin ... Kranckheiten, oder den Todt selber beybringen können .... Erfurt, 1593.

Slim, Colin. "Mary Magdalene, Musician and Dancer." Early Music 8 (1980): 460-73.

Spina, Bartolomeo della. Quaestio de Strigibus. Rome, 1576.

Venjakob, Judith. Der Hexenflug in der frühneuzeitlichen Druckgrafik: Entstehung, Rezeption und Symbolik eines Bildtypus. Petersberg: Michael Imhof, 2016.

Vervoort, Renilde Bruegel's Witches: Witchcraft Images in the Low Countries Between 1450 and 1700. Translated by Paul and Gregory Arblaster. Bruges: Van de Wiele, 2015.

Vintler, Hans. Buch der Tugend. Gotha, c.1500; Vienna, c.1400-1450.

Voltmer, Renata. "'Hört an neu schrecklich abentheuer von den unholden ungeheuer': zur multimedialen Vermittlung des Fahndungsbildes 'Hexerei' im Kontext konfessioneller Polemik." In Repräsentationen von Kriminalität und öffentlicher Sicherheit: Bilder, Vorstellungen und Diskurse vom 16. bis zum 20. Jahrhundert, edited by Karl Härter, Gerhard Sälter and Eva Wiebel, 89-163. Frankfurt am Main: V. Klostermann, 2010.

Williams, Gerhild Scholz, ed. and trans. On the Inconstancy of Witches: Pierre de Lancre's Tableau de l'inconstance des mauvais anges et demons 1612. Tempe: Arizona Center for Medieval and Renaissance Studies; Turnhout: Brepols, 2006.

Wüthrich, Lucas Heinrich. Das druckgraphische Werk von Matthäus Merian d.Ä. Vol.1, Einselblätter und Blattfolgen. Basel: Bärenreiter, 1966. 


\section{Charles Zika}

Zika, Charles. The Appearance of Witchcraft: Print and Visual Culture in Sixteenth-Century Europe. London and New York: Routledge, 2007.

Zika, Charles. "Visual Signs of Imminent Disaster in the Sixteenth-Century Zurich Archive of Johann Jakob Wick." In Disaster as Image: Iconographies and Media Strategies across Europe and Asia, edited by Monica Juneja and Gerrit Jasper Schenk, 43-53, 217-220. Regensburg: Schnell und Steiner, 2014.

Zika, Charles. "Recalibrating Witchcraft through Recycling." In The Primacy of the Image in Northern European Art, 1400-1700, edited by Debra Cashion, Henry Luttikhuizen and Ashley West, 391-404. Leiden: Brill, 2017.

Zika, Charles. "The Transformation of Sabbath Rituals." In Emotion, Ritual and Power in Europe, 1200-1920: Family, State and Church, edited by Merridee L. Bailey and Katie Barclay, 261-84. London: Palgrave Macmillan, 2017.

Zika, Charles. "The Witch and Magician in European Art." In The Oxford Illustrated History of Witchcraft and Magic, edited by Owen Davies, 134-66. Oxford: Oxford University Press, 2017.

Zika, Charles. "Emotions, Exclusion and Witchcraft Imagery." In The Routledge History of Emotions in Europe: 1100-1700, edited by Susan Broomhall and Andrew Lynch, 233-55 Abingdon, Oxon: Routledge, 2020. 